\title{
SOUTHEAST ASIA: HISTORY, MODERNITY, AND RELIGIOUS CHANGE
}

\author{
Sumanto Al Qurtuby \\ University of Notre Dame's Kroc Institute for International Peace Studies
}

\begin{abstract}
Southeast Asia or Southeastern Asia, with more than six hundred million populations, is home to millions of Buddhists, Muslims, Confucians, Protestants, Catholics, and now Pentecostals, as well as many followers of local religions and spiritual beliefs. Notwithstanding its great historical, political, cultural legacies, however, the region has long been neglected as a site for religious studies in the Western academia. Aiming at filling the gap in Asian and religious studies as well as exploring the richness of Southeast Asian cultures, this article discusses the dynamics, diversity, and complexity of Southeast Asian societies in their response to the region's richly political, cultural, and religious traditions spanning from pre-modern era to modern one. The article also examines the "integrative revolutions" that shaped and reshaped warfare, state organization and economics of Southeast Asia, particularly in the pre-European colonial era. In addition, the work discusses the wave of Islamization, particularly since the nineteenth century, as well as the upsurge of religious resurgence that shift the nature of religiosity and the formation of religious groupings in the area. The advent of Islam, with some interventions of political regimes, had been an important cause for the decline of Hindu-Buddhist traditions in some areas of Southeast Asia, especially Indonesia, the coming of Pentecostalism has challenged the well-established mainstream Protestantism and Catholicism, especially in Indonesia and the Philippines.
\end{abstract}

Keywords: history, modernity, religious change, Southeast Asia

\section{PRE-MODERN SOUTHEAST ASIA: THE POWER OF HINDUISM-BUDDHISM}

It is imperative to note that based on archeological sources, people living in the regions of today's Southeast Asia ${ }^{1}$ who were skilful in "casting metals and making pottery" were as early as 3000 years BCE (Osborne 2002: 21), signifying that the history of Southeast Asia's civilizations is as old as that of Egypt's, Greece's, India's, and China's. Although the region has prolonged historical records, however, it is not until the first centuries of $\mathrm{AD}$ that the region's cultures and civilizations become visible. Known as the Southeast

1 Southeast Asia is a sub-region of Asia consisting of the countries that are geographically south of China, east of India, west of New Guinea, and north of Australia. 
Asia's Golden Age, this classical era had been marked by the appearance of great cultural achievements crafted by the early actors of the Indic states. These remarkable accomplishments, achieved by the "Indic" courts that were scattered across Southeast Asia, were later followed or replaced by what the noted historian of Southeast Asia Anthony Reid $(1988,1995)$ has called the "Age of Commerce" typified by the dynamics of global trade involving foreigners of various professions such as, among others, merchants, teachers, gurus, Sufis, travelers, and priests coming from around the world: China, India, Persia, Bangladesh, Arab and the Middle East, Ceylon, and Madagascar, to name but a few (see also Lombard 1996).

The region of "pre-modern" Southeast Asia was divided into two main categories: mainland / inland and maritime, each of which has special characteristics in terms of its people, along with their cultures, divisions of labor, social living, organization, traditions, technologies, and system of beliefs. Later, as I will discuss below, such distinctive features of the mainlandmaritime influenced the forms and characteristics of the region's traditional states or courts. Moreover, the mainland region, known as Indochina comprising Cambodia, Laos, Burma (Myanmar), Thailand, and Vietnam, was divided into two major areas, namely upland and lowland. Historian Milton Osborne (2002: 65; 2000: 53) calls it "hill-valley division." People living on the upland territory have also different features from those who lived on the lowland. While peasant farmer was part of the dominant society of the lowland, the nomadic farmer who practiced "slash and burn agriculture," in addition to hunter-gatherer, composed the striking marks of the "hill people" in traditional Southeast Asia. Most minority highlanders did not share the dominant lowland society's values and cultures. Additionally, most majority lowlanders often considered the peoples of the highland as savage, barbarian, primitive, and uncivilized groups. Such stereotyping suggests that the split of upland-lowland is not merely a geographical separation, but-this is the most important thing-socio-cultural division. The people of the lowland who controlled the governments also did not involve the uplanders in their decision-making process and other governmental-political issues. As a result, the highlanders became "out-groups," albeit they played a variety of significant roles across the regions of Southeast Asia such as a source of slaves, trade of forest products, and magical power.

Unlike the mainland of traditional Southeast Asia in which its inhabitants were divided into upland and lowland dwellers, the real division in the maritime regions (such as Indonesia, Brunei, Malaysia, the Philippines, Singapore, East Timor, among others) was, to borrow Osborne's phrase, "those who followed 
a pattern of life related to a permanent base" (e.g. for fishing, trading, and farming) and those who pursued "a nomadic life combining hunting and slash and burn agriculture." Whereas in the mainland the nomadic farmer was highlanders, that was not the case in areas of the maritime. Apart from the details of differences between the mainland/inland and the coastal areas, it is common to acknowledge that the mainland was marked by agrarian societies while the maritime areas were typified by trading and fishing-based economic systems (see also SarDesai 1997).

It is significant to note that there were no massive state-based societies in the region until the arrival of Indian Buddhist priests and Hindu Brahmins, which later drove the establishment and transformation of local small states to, a sort of "Indic" courts/states across the Southeast Asia's interior and coastal areas. The word "state" highlighted here, it should be noted, is not in the sense of modern-nation states, but rather in the term of old-fashioned state/government that was characterized by (1) no clear physical boundary since it was not a territorial state (as a result, rulers fought and controlled over followers not territory); (2) lack of bureaucracy, and indeed there was no bureaucrat in the sense of today's modern-state; (3) patrimonialism in which the relationship between the rulers and the ruled was not built based upon professional ties but "patron-client" and personal connection with a ruler; (4) lack of government structure so that no bureaucratic continuity; (5) no standing army; and (6) no mechanism or rule of succession, so that the process of transformation of power could be violent. Vietnam was the only country in Southeast Asia's early history that had a sort of "modern" government typified by bureaucracy, structures of governments (from central to village level), education, professionalism, and a written code as the law. While in the "Indic" states (in Burma, Thailand, Cambodia, or Java) the officialdom was a quasi-hereditary affair, in Vietnamese state bureaucracy was open to all citizens who could meet the tests of scholarship. Vietnam's "uniqueness" can be understood, in part because it was the only region in Southeast Asia that was "Sinicized" rather than "Indianized" (see Osborn 2000: 35-41).

Furthermore, the legacy of those "Indic" states in Southeast Asia's classical history can be traced back to the foundation of a number of great classical kingdoms scattered from Angkor of Cambodia to Tarumanegara of West Java, from Champa to Kutai of Kalimantan. ${ }^{2}$ Perhaps only Sulawesi and Maluku

2 Examples of these early "Indic" empires stretching from early centuries AD to $13^{\text {th }}$ and $14^{\text {th }}$ centuries included Angkor of Cambodia, Pagan of Burma, Champa (in Southern Vietnam), Srivijaya of Sumatra (its center is believed in today's Palembang), Gangga Negara (located in today's Perak, Malaysia), Langkasuka (located in the Malay Peninsula), Pan Pan (situated in modern Kelantan or Terengganu, Malaysia), Salakanagara (sited in today's Pandegelang of West Java), Tarumanegara (its power scattered from modern Banten, Bogor, 
had not been influenced by Hinduism-Buddhism. There are no temples and other Indian artifacts so far in both eastern regions of Indonesia. Apart from Sulawesi and Maluku, most, if not all, the greatly classical kingdoms in Southeast Asia were associated with Buddhism (especially Mahayana Buddhism), Hinduism, or both (and in some cases mixed with indigenous beliefs). Effected by Southeast Asia's features and physical environments, these classical empires can also be characterized into two main streams: land-based states centering agricultural systems and agrarian societies, and maritimebased empires focusing on trading or a sort of "mercantile state." While Angkor of Cambodia was one of the mightiest examples of the land-based empires, Srivijaya of Sumatra was the main powerful maritime-based kingdom in Southeast Asia's classical stage that built its enormous power based on the networks of international trade and China's sponsorship (Tan 2009).

With the exception of Vietnam, which was deeply-rooted and influenced by Chinese-Confucian traditions and politics; thereby extensively differed from other territories of Southeast Asia in terms of state organization, as well as the Philippines (and perhaps Brunei?), which was never touched by Indian cultures, Southeast Asia's regions in the classical era deeply experienced a process of what so-called "Indianization." Indeed, there has been a debate to how Indian cultures and politics come to play its part in the early stages of Southeast Asian history and about the degree of its significance. Such debate can be understood in part because there was never any major or waves of huge migration of people from India to Southeast Asia. Instead, only a limited number of people, some of them were Brahmins (Hindu priests), Buddhist monks, scholars, and traders searching for routes, ${ }^{3}$ did travel to Southeast Asian regions that were famous as the lands or islands of gold. Once the Indian priests-scholars landed and reached the small-scale "states" just appeared in the region, they found that their religions-Hinduism and Buddhism-proved attractive to the local rulers and their inhabitants (see e.g. Lockard 2009).

Some scholars have argued that a primary reason of the attractiveness toward Indian cultural ideas attached in Buddhism and Hinduism partly because these religions fitted perfectly with the local religious beliefs and worldviews existing in (some) areas of Southeast Asia. To put it differently, the Indian

and Jakarta), Kutai Martadipura (in East Kalimantan. Its founder, Kudungga, was a Buddhist from the royal family of Champa court), Kalingga (located in today's Keling of Jepara, and its popular king, Ratu Shima, has been called "the classical Srikandi of Javanese society"), and Mataram Kuno in Central Java (either related to Wangsa Sanjaya or Wangsa Syailendra which were the actors of the formation of Central Java's great temples: Borobudur, Prambanan/Lara Jonggrang, and Kalasan).

3 The traders travelled to the east from India because of a decision made by the Roman Emperor Vespasian who banned the export of gold to India. 
cultures, traditions, and knowledge were absorbed by the local rulers and populations, and were joined to their existing cultural patterns. Local spiritualcultural concepts of the cosmic duality, for instance, resembled those of Indian "dewa-dewi" (lit. god-goddess). Local beliefs toward "sacred mountains," along with its guardian spirits, as a source of the balance of universe (see e.g. Geertz 1976; Beaty 1999) also nicely fitted Hindu-Buddhist idea of Mount Meru (also called "Sumeru" meaning the "Great Meru"), a sacred mountain in Hindu-Buddhist cosmology (as well as in Jain mythology). For local believers in Java, the Mount Meru is considered to be the center of all the physical, metaphysical, and spiritual universes. For Indian Hindus, it is believed that the Mt. Meru is to be the adobe of Brahma (the Hindu god of creation) and other gods (devas). As well, Indian veneration of the lingam, an image in stone of the Hindu god Shiva's phallus and so symbolizing both divine and earthly generative powers, is believed to have fitted well with a similar veneration in Southeast Asia of erect stones as fertility symbols (cf. Schrieke 1957).

Another reason of why Buddhism and Hinduism were eye-catching local rulers and their subjects was the "custodians of knowledge" Hindu Brahmins and Buddhist monks brought and offered to them. Nothing to do with religious concepts, these "custodians of knowledge" that the Brahmins and monks carried out during early phases of Southeast Asian history related to those of astronomy and astrology, of architecture, and of statecraft. In the eyes of local rulers, all these things were very useful to be used as a means of governing societies, of crafting a temple, court and building, of expecting a major astronomical event, etc., along the way of religious symbolism. Local histories and oral traditions scattered from Cambodia to Sunda telling the meeting and relationships between Brahmins and monks with local rulers confirmed the influence of these Indian priests to local kings.

However it is central to notice that whatever the significance of imported Indian knowledge and cultures and their meeting with the existing local religious beliefs, cultural patterns, and worldviews, there were some vital aspects of Southeast Asian life that never took roots within Indian cultures. In addition, in some cases, a number of fundamental Indian religious systems and cultures were never adopted by Southeast Asian Hindus such as the strict caste system (i.e. brahma, ksatria, waisya, sudra, and paria). As well, while in India temples function as a congregational life, Southeast Asia's temples were dedicated to courts and kings. Although Indian religions, art forms, and systems of government had been at the center of Southeast Asian life and cultures, these "cultural endowments" had been localized in accordance with "local tastes." In brief, Southeast Asians, indeed, borrowed and absorbed Indian religious 
beliefs and knowledge but they also adapted these cultural gifts in accordance with local cultures and traditions. This is to say that Southeast Asians were neither "active givers" nor "passive recipients." The process of "Indianization" hence should be viewed as neither Southeast Asian total acceptance of Indian cultural values nor the complete transformation of Southeast Asian cultural and political features into Indian nature. In fact, there were a number of cultural patterns that still unique Southeast Asia such as, among others, gender relationships, female peasants, and wet-rice cultivation techniques.

\section{THE AGE OF COMMERCE AND THE ADVENT OF ISLAM}

The glory of Hinduism/Mahayana Buddhism-based classical empires had come to an end sometime in the $14 / 15^{\text {th }}$ century after the downfall of Cambodia's Angkor and Sumatra's Sriwijaya. The Angkor was replaced by powerful Thai peoples while Sriwijaya was transformed into a new dominant Islamic sultanate of Malacca, which later sponsored "Islamization" to Malay regions, Brunei and Borneo, and eastern Indonesia such as Sulawesi (e.g. the Kingdom of Gowa) and North Maluku (Sultanates of Ternate, Tidore, Bacan, and Jailolo). The collapse of the great kingdoms of Angkor and Sriwijaya had been followed by the rise of the new era so-called the "Age of Commerce" that marked Southeast Asia's pre-European colonial history, as well as the end of Southeast Asia's classical era. This particular phase was very dynamics in terms of cultural and commercial flow since there were various social agents and peoples in the region coming from different part of the world.

The driving forces of this "Age of Commerce" included, but not limited to, first, spices which were far more expensive than gold that had been at the core of foreigners travelling to Southeast Asia in the "classical" period; second, military or political expedition of China-Mongol from the Yuan Dynasty. Sometimes in the 1289s, the emperor Kublai Khan (r. 1260-1294) sent some 20.000 armies to Java to defeat the King Kertanegara of Singasari in East Java and forced it to be a tributary state; and third-and this is the most remarkable one-the contact establishment between the Ming Dynasty and Southeast Asia regions. Born in 1370, Cheng Ho (Zeng He), it was believed to be a Hui Muslim, was the main legendary figure of this contact who led huge expeditions to the coastal areas of Southeast Asia since the early fifteenth century.

The Ming Shi ("the History of Ming Dynasty") recorded that Cheng Ho's fleet was involved 62 big ships and 225 junk (boats) along with 27.550 marines, astronomers, politicians, map makers, doctors, traditional healers, preachers, ethnographers, etc. (Tan 2009; Nio 1952). From 1405 to 1433, Cheng Ho had 
conducted the expedition for seven times ${ }^{4}$ and visited more than thirty seven countries: from Indonesian seaports, notably Palembang, Banten, Cirebon, Semarang, Gresik, and Surabaya to Ceylon, Kocin, Kalikut, Ormuz, Jeddah, Magadisco and Malindi, from Campa to India, from Persian Gulf to Red Sea and the coast of Kenya. Cheng Ho's expeditions were not only for the economic and political purposes, but cultural and religious concerns as well.

As a result of the influx of peoples and merchandise from various parts of the world, Southeast Asia from fourteenth to sixteenth century, just about the coming of European colonials, had been the world's most prosperous trading centers. Witnesses and records of early travelers who transited to Southeast Asia's coastal areas in the $14^{\text {th }}$ to $16^{\text {th }}$ centuries such as Marco Polo, Ibnu Battuta, Ma Huan, Loedewicks, de Houtman, to name a few, can be used as evidence of the dynamics and advancement of Southeast Asia throughout those centuries. Accordingly claims have been made by some specialists of Southeast Asia that the period between the $13^{\text {th }}$ and $16^{\text {th }}$ century was a stagnant/static era separated from the glorious classical "Golden Age" resulted in the mightiest cultural monuments and the heroic colonialism beginning in the late sixteenth century need to be reevaluated.

The emergence of the "Age of Commerce" was indicated by a number of fundamental features: (1) the growth of urban cities (it is said the increase was three times much bigger that European cities); (2) the plurality of ethnicity and religion; (3) the growth of personal wealth (Malay/Indonesian: "orang kaya") that marked the emergence of a new class of wealthy people (indicated by the ownership of merchant fleets and ships); and (4) contractual package of government distinctive from the "old" fashioned raja-centric states. Here, the appearance of a new class of rich people and merchant groups had been able to change the nature of politics and state government as well as the patterns of the relationship between the ruler and the ruled. While in the "old" states the status of "elite people" was only determined by hereditary system, i.e. only those inherited the blood of kings, princes, courters, or Brahmins (Indonesian: "darah biru") who were able to reach the elite class, during the "Age of Commerce," the new class of rich people and merchant groups could

4 The first expedition (1405-07) was from Nanjing to Calicut, Champa, Java, Srivijaya, Sumatra, and Ceylon; The second expedition (1407-09) was a voyage to India and to install the new king of Calicut; The $3^{\text {rd }}$ expedition (1409-11) was to Champa, Temasek, Malaka, Sumatra (Samudra and Tamiang), and Ceylon; The fourth one was (1413-15) was a voyage to Champa, Java, Sumatra, Malaya, Maldives, Ceylon, India, and Hormuz; The fifth trip (141719)'s destination was Champa, Java, Palembang, Aden, Mogadishu, Brawa, and Malindi on the west coast of Africa; The sixth voyage (1421-22) was to Africa and all over the world including America (Menzies 2003); and the seventh expedition (1431-33) was to southern Vietnam, Surabaya, Palembang, Malaka, Samudra, Ceylon, Calicut, Africa, and Jeddah (see e.g. Widodo 2003) 
achieve such status and negotiated or bargained power/authority with local rulers. In some cases, many princes' daughters were also married to these wealthy merchants, a tradition that was alien in the time of "old" states.

Furthermore, the transition from Hinduism and Mahayana Buddhismbased states to the new "Age of Commerce" had been marked by a massive conversion to Theravada Buddhism (especially in the mainland of Burma, Cambodia, Laos, Thailand, and southern Vietnam) and Islam (esp. in the Malay Peninsula, Brunei, Sumatra, and northern coast of Java). Such rapid collapse of Hinduism and Mahayana Buddhism was partly because these religions were (1) lack of deep social roots, and (2) king-centric religions. As a result when the kings and courts collapsed their religions disappeared. It happened in the mainland of Southeast Asia like Burma: the real spread of Theravada Buddhism since the $13^{\text {th }}$ centuries was because its kings embraced this new form of Buddhism and built temples around their kingdoms.

This is to say that the spread of Theravada Buddhism from Sri Lanka to Burma was by courts, not trade or conquests. Apart from the role of princes and empires in the proliferation of the Theravada, this new "reformed Buddhism" differed significantly from the "old" Mahayana in term of the principles of religious knowledge, doctrines, and cultures that might be contributed to the development of this new Theravada Buddhism. In addition, unlike the Mahayana which was lack of social roots the Theravada built Sangha, a religious establishment surrounded around the kings, through which this religion became deeply rooted. The Theravada was also seen to be more "democratic" than the Mahayana, and women could become a priest leading rituals and religious liturgy.

Whereas in Burma, Cambodia, Thailand, Laos, and southern Vietnam had undergone the process of top-down "Theravada-ization," Southeast Asia's coastal regions such as today's Malaysia, Sumatra, and northern Java had converted to Islam through a vehicle of trade, Sufism/mysticism, art performs, etc., a sort of "bottom-up" conversion through cultural means of knowledge productions. Southeast Asia's conversion to Islam since the $13^{\text {th }}$ to $17^{\text {th }}$ centuries was through multiple channels of religious actors. However, the main carriers of Islam in the region were Sufi-mystics and traders coming from China, Arab and the Middle East countries, India, Bengali, Persia, etc. Steadily but surely this new forces of Muslims were able to transform Southeast Asian peoples and established small, but significant Islamic kingdoms centered in Demak (Central Java), Giri (East Java), and Cirebon (West Java) (all located in northern coast of Java). By the end of $15^{\text {th }}$ and early $16^{\text {th }}$ centuries, these new Muslim movements had successfully toppled the last powerful Java-based 
Hindu-Buddhist kingdom Majapahit. The description and analysis I sketched above suggest that the "integrative revolutions" occurred in pre-colonial Southeast Asia were primarily due to the waves of religions and civilization.

\section{WORLDVIEWS, BELIEFS, AND RITUAL PRACTICES}

Before the arrival of the new world religions, to borrow Max Weber's (1993) phrase, especially Islam, Theravada Buddhism, and Christianity, in the fifteenth century, Southeast Asian societies practiced a sort of traditional religious beliefs and Hinduism (or Hindu-Buddhist traditions as those of Singasari and Majapahit kingdoms). As I briefly described in the previous paragraphs, Southeast Asia's traditional and indigenous religious practices were characterized by, first, the worship of guardian and ancestral spirits (Javanese: danyang or roh mbahu rekso) by offering meals and other things (flower, incense, water, etc.) needed for the rituals. Later these ritual practices of guardian and ancestral-spirit veneration had been absorbed and practiced by local rulers and palace's elites. Indeed, local kings and its courts sponsored these indigenous religious events such as the Javanese and Malay rulers' annual offerings to spirits of the sea (e.g. Nyai Lara Kidul for the spirit of South Sea or Dewi Lanjar for that of the North/Java Sea). Not only rulers (or "states") that have practiced such religious festivals, Muslim societies also still preserve such rituals like the nyadran traditions in northern coast of Java. The Javanese literature expert from the Netherlands Theodore Pigeaud (1962) also noted that Majapahit's successors maintained ritual ceremony of pre-Islamic courts, and cultivated an aesthetic and mythical tradition influenced by earlier traditions.

The second characteristic of "indigenous" religion was animism" (from Latin word anima meaning "soul" or "life"). The late American anthropologist Clifford Geertz (1976: 5) once noticed that the sort of animism was not only common in Java but also in many of the pagan tribes of Malaysia prior to the coming of the world religions. However, this tradition, Geertz continued, has proved, over the course of the centuries, remarkably able to absorb into "one syncretized whole elements from both Hinduism and Islam," which follow it in the fifteenth century. Before the "incursion" of reformed Islamic religion in the nineteenth and twentieth centuries, Southeast Asia's Muslims still practiced a syncretic form of religious beliefs. As in the case of Java, the village religious system commonly consisted of a "balanced integration" of animistic, Hinduistic, and Islamic elements, a basic Javanese syncretism which is the

5 Animism is a philosophical, religious, or spiritual idea that souls or spirits exist not only in humans or animals but also in plants, rocks, mountains, rivers, etc. 
island's true folk religion. Religious practices of the Javanese abangan resemble Cambodia's Imam San who has claimed to be the keepers of ancient Cham rituals, language, and traditions. Rites of life passage in Tengger, as Hefner remarks, are also celebrated in a "syncretic form" combining various elements of ancient Javanese traditions.

Third, another common theme of Southeast Asia's religious practice prior to the advent of the new world religions dealt with the concept of cosmology, or more precisely, the worldview of the sacred duality, that is a sort of belief (or wisdom) that preserve the significance of the integration of opposing entities: land-water, male-female, sea-mountain, earth-sky, micro-macro cosmos, and so forth to keep the harmony of social order and cosmos. Indeed, preservation of "cosmos balance" such as the harmony of male-female, dewadewi, gods-goddesses, water-mountain (read, cosmic duality) through certain ritual performances had been the central theme of pre-Indic Southeast Asian societies. This is to say that creation and recreation of the world through harmonious ways had become a primary concern of these traditional peoples. The practices of exorcism (a spell), artistic performance, and spirit cultism which still survived into the twentieth century are other features of pre-world regions Southeast Asia.

In addition to the above indigenous religious traditions, Southeast Asia prior to the entrance of the new world religions was colored by Hinduism. The historian of Southeast Asia Oliver Wolters (1993) said that the dominant impulse in Hindu religious beliefs was a "devotional" and personalized one (bhakti), organized around popular cults in honor of Shiva and Vishnu. No doubt, Hinduism (and Mahayana Buddhism-Hinduism) had been at the core of classical Southeast Asian traditions. Classical empires such as Gangga Negara, Langkasuka, and Pan Pan (all located in modern Malaysia), Salakanagara, Tarumanegara (sited in today's West Java), Kutai Martadipura (East Kalimantan), Kalingga (Jepara), as well as the great Singasari and Majapahit had been strongly influenced by Hinduism. The term "Indianization" of Southeast Asia as Wolters once used it referred to the influence of Indian Hindu, and therefore religious or cultural rather than political conceptions that brought ancient and persisting indigenous beliefs into sharper focus. In other words "Indianization" of Southeast Asia took roots in the forms of culture, art, language, scholarship, and above all, religion. Historical records, epigraphs, writings, archeological sites, classical monuments, etc. all confirmed Hinduism (or Hindu-Buddhism)-driven Southeast Asia’s great cultural achievements.

Unfortunately, unlike in India, where much of the non-Islamic infrastructure survived the Muslim conquests, Southeast Asia's temples and monasteries of 
Hindu-Buddhist worship as well as historical sites (epigraphs and learning centers included) experienced a near-total collapse in the centuries following local rulers' conversion to Islam. Hefner (2009: 14) noted that before the Islamization of its courts took place in the $15^{\text {th }}$ and $16^{\text {th }}$ centuries, Java's kingdoms had some two hundred centers of Hindu-Buddhist monasticism and learning, none of which survived into the modern era except a small Hindu Javanese enclave of East Java's Tengger! In the centuries following the fall of the last "Siwa-Buda" kingdom of Majapahit, Java's Hindu-Buddhist priestly communities and elements of Indic heritage slowly disappeared except in some isolated areas of the eastern salient and Tengger (cf. Hefner 1989). Again, this historical evidence shows the fact of "raja-centric" religious traditions so that when the courts collapsed, peoples would follow new rulers' religions.

Although the role of courts in the process of the spread of religion (Islam included) was significant, it does not mean to diminish the contribution of other agents. As I will describe below, besides priyayi elites of the court, the role of kiai, haji, habib, sayid, dukun, pastor or priest (e.g. Kiai Sadrach), and other non-courtly local leaders as a transmitter of knowledge, religiosity, and cultures was very significant. This phenomenon did not only happen in Java or Indonesia, but all-across Southeast Asian regions. In the Philippines, for instance, the role of pandita or guru in the transmission of knowledge and learning process was also very central (see e.g. McKenna 1998). Hefner (2009: 11) also noted that the role of religious experts like dukuns, bomohs (Malay), and shamans scattered across the Southeast Asia regions before their position had been taken place by religious teachers and ulama.

\section{MODERNITY AND THE RISE OF ISLAMIC REFORMISM}

Furthermore, it is central to acknowledge that although since the $14^{\text {th }}$ or the $15^{\text {th }}$ century parts of Southeast Asia had already begun to be Islamized, especially in the areas of mercantile ports, it was only in the nineteenth and twentieth centuries that the process of Islamization and the creation of Islamic public culture took its deep roots and experienced a vast impact through, among other things, the development of broad-based institutions for intermediate and advanced education in the Islamic sciences, including jurisprudence and Islamic canon. This is also the case in South Asia. As Muhammad Qasim Zaman, a professor of Near Eastern Studies and Religion at Princeton University, has argued in his recent book Modern Islamic Thought in a Radical Age, the establishment of the Muhamamdan Anglo-Oriental College, founded by Sayyid Ahmad Khan (d. 1898) in 1875 in the north Indian town of Aligarh, 
as well as the Darul Ulum of Deoband in 1866, both became a primary channel for the process of Islamization and the shape of South Asia's Islamic public culture (Zaman 2012: 4-6).

This analysis, however, does not suggest that there was no Islamic public culture in Southeast Asia prior to the $19^{\text {th }}$ and $20^{\text {th }}$ centuries. Indeed Islamic public culture had existed before these centuries, but it was produced and reproduced by or through sultans or kings-sponsored religious rituals, and not institutionalized religious schooling. As well, although madrasas-based Islamic education began to take place in the late $18^{\text {th }}$ and $19^{\text {th }}$ century, it does not mean that there was no Islamic learning in the region. In the Malay Peninsula, for instance, the earliest form of Islamic education since the arrival of Islam in the region was Quranic recitation, held in mosques, prayer houses (Javanese: langgar), or in the homes of learned Muslims (Hefner 2009: 112). Prior to the "invention" of modern schools, the introduction and dissemination of Islamic knowledge were conducted in, particularly in Java, the prayers houses or in the homes of Sufi-mystics and dukun (or shaman, a traditional healer), a sort of Egypt's syaikh ummi, an uneducated religious teacher who claimed to attain his Islamic knowledge from visions of the Prophet and the depths of his heart, and not from the reading of Islamic texts (see Hefner 2009: 11).

As other regions of Southeast Asia, Java in the nineteenth century also underwent an enormous change that contributed to the development of Islam. Java's rapid change, more specifically, was triggered and caused by the deadly Java War from 1825 to 1830 and the massive famine that hit Central Java in the $19^{\text {th }}$ century. Such poverty and landlessness were also widespread in East Java and Madura during that period. This tragic event had caused tens of thousands of people died, causing the drop dramatically of Java's population, while others migrated and fled to East Java. The Dutch administration itself also encouraged the migration for coffee cultivation purposes (Hefner 1989: 242). Accordingly it is understandable why much of the labor required for coffee agriculture in the Tengger highlands and other places of the eastern salient, as Hefner noted (ibid: 33) was provided by Central Javanese and Madurese immigrants. That coffee cultivation, a product of the Dutch-imposed cultuurstelsel or cultivation system whose architect of which was the Governor-General van den Bosch, was triggered by the bankruptcy and economic/financial crises of the VOC (the Dutch East India Company) at the end of the $18^{\text {th }}$ century after nearly two centuries in the Indonesian archipelago without significant outcomes in terms of economic benefits. In particular, the Prince Diponegoro-led five-year Java War (1825-1830) had caused a major devastation. ${ }^{6}$

6 Triggered by such lost money and economic crises, van den Bosch (1780-1844) proposed to King Willem I (1813-40) to extract agricultural products such as indigo, sugar, 
A century-long movement of migration from Central Java and later from the island of Madura to the areas of East Java, including those of Tengger, a bit by bit had colored and transformed this eastern salient area's local cultures and traditions as well as had changed its society's economy. The Madurese, originally came as migrant workers on Dutch-owned lands, have set two distinct social classes: first is a small group of wealthy entrepreneurs who acted as labor managers and coffee agents for the Chinese and Dutch, and second is a much larger class of landless laborers who were brought by the entrepreneurs to work the land, known as santri in the sense of both "workers" and "orthodox" Muslims. The influx of Muslim migrants had pushed back the followers of Buda religion into the interior of rural villages and mountains (e.g. Hindu Tenggerese). Nonetheless the Islamic population continued to grow significantly in the $19^{\text {th }}$ century "as a result of government policy giving land titles to both the coffee lords and their previously landless dependents" (Hefner 1987a: 59-60).

One of the key factors underlying cultuurstelsel output, according to the historian M.C. Ricklefs (2007), was the investment of Javanese labor, not land, into agricultural production for the government. It is central to remember that since the cultuurstelsel needs the involvement of labor to make it successful the idea of how to mobilize labor became crucial. In an attempt to achieve this goal, the Dutch collaborated with the Javanese elites: priyayi. In a stratified society with feudal political system like Java, the role of priyayi who held "traditional" authority at the time was central in organizing Javanese labors and peasants to grow coffee, sugar, indigo, tea, pepper, tobacco, cinnamon, etc. Hence it is understandable that the contribution of priyayi was fundamental to the entire system of cultuurstelsel. During the period of cultuurstelsel there were two contrasting views, on one hand, many of the priyayi elite and village landowners prospered. Officials also received good salaries, percentages on crops compulsorily produced by the peasants under their authority.

The system, furthermore, stimulated the rise of a nascent middle class society who was able to build better houses, to advance their businesses, to educate their children, to go to Mecca to do hajj, and to some degree, to embrace Islamic reform movements. They often had businesses and religious links with the Arab communities found especially in the coastal towns and cities of Java (known: kampong Arab). However, on the other hand, as a result of the cultuurstelsel, many peasants suffered and died due to devastating famines and

and above all, coffee from Java in a volume and at a price that would be enable the Netherlands to become one of the world's greatest suppliers of those tropical products and, by definitions, brought the lost money back. And this task would be successful, van den Bosch suggested, in a way that would benefit the Javanese themselves (Ricklefs 2007: 12-3). 
outbreaks of epidemics (c. 1846-50). Thus, to sum up, in the mid-nineteenth century Javanese society had polarized into three social groups: the priyayi elite (bupati and government officials included), a promising Muslim bourgeoisie, and peasants. These social groups are not only a matter of class differences, but they also differed in fundamental ways: cultural and religious orientation, aspirations, and the relationships to the dominant colonial power (Ricklefs 2007: 12-29).

Furthermore, the introduction of coffee in East Java, particularly in the region of "Besuki" had not only changed "the village's ethnic and religious composition but had also introduced a new mode of production in which the Buda population was a distinct disadvantage" (Hefner 1987: 60). In other words, Muslim immigration and coffee cultivation-and sugar in areas of Pasuruan-not only changed the economy of the mountain terrain and rural villages but brought about the first stage of its Islamization as well. As a result of the economic advances and the growth of Muslim population, by the midnineteenth century, most of Hindu Tenggerese had been pushed further up into the highlands or assimilated into the economically dominant immigrant Muslim population (Hefner 1989, 1987b) so did local people of other regions outside Tengger. As well, due to this economic development, these Muslim communities were able to build religious institutions: schools (pesantren), mosques, and prayer houses (mushalla or langgar) which did not exist in the areas of Tengger prior to the final quarter of the nineteenth century or early $20^{\text {th }}$ century. These Islamic institutions, on one hand, had enormously played major contributions to the development of Islam and the decline of "HinduBuda" religion on the other.

Indeed, seen from Islamic perspective, the nineteenth century of Java and Southeast Asia in general had been marked by a number of crucial changes: (1) the increase of the number of Muslims who took pilgrimage to the Holy Land as an impact of the opening of Suez Canal; (2) the spread of Islamic boarding schools (Javanese: pesantren) across Southeast Asia's regions, particularly Indonesia and the Malay Peninsula; (3) the growth of Sufi tarekat brotherhoods, and (4) the growing of orthodox, fundamentalist, and reformist Muslims. All these factors had contributed to the development of reformed Islam, the decline of "traditional" religions (including Hinduism), the tensions among Muslims sub-groupings (e.g. traditionalists versus reformists, Sufimystics vis a vis legal-minded Muslims, among others), and the emergence of anti-colonial movements that challenged colonial authority. No doubt haji and kiai in the nineteenth centuries had enormously played significant role not only as a charismatic religious figure directing religious ceremonies and 
Islamization processes but also a political leader taking the lead socio-political movements against the Dutch and the colonial-backed local aristocrats as in the cases of the Banten War in 1888 and the resistance of Kiai Ahmad Rifa'i, along with his Rifa'iyah in Central Java (Kartodirdjo 1973, Djamil 2001).

Due to the influx of a sort of purified Islam, Ricklefs (2007: 252-3) characterizes the nineteenth century Java as the era of the rise of Islamic reform and revivalism. He argued that Islamic reformist notions evidently began to have an influence in Java in the 1850s, about half a century after "Islamic reformation" took place in Minangkabau of Sumatra. Arab communities of Java's pasisir (coastal areas) towns seemed to have a leading role as carriers and transmitters of Islamic reform ideas. One of the Arab leaders was Hadharami Sayid Uthman bin Aqil bin Yahya al-Alawi (d. 1913), who became a leading voice for reformist Islam. His publications of more than 100 titles remained influential among Java's Arabs and reformist Muslims. Likewise the increasing numbers of haji before and after the opening of the Suez Canal in 1869, the growing numbers of pesantren, and the spread of printing media, Ricklefs has noted, had played a major role in transmitting and spreading ideas of purified and reformed Islam (cf. Hefner 2009). The forms of reform Islam and reformist Muslims themselves varied ranging from Puritanism (purification-oriented Islam), anti-Sufism faction, shariah-minded groups, shariah-based Sufism, and reformed traditionalists, to name but a few. Although they might differ from one to another in their focus and objective, however, the basic ideas of the Muslim reformists mostly the same, namely the eagerness to make Islam more pristine as it was performed by the salafus-salih (lit. the "pious forebears", namely the early generations of Muslims) by avoiding non-Islamic aspects of local traditions, cultures, and practices. Accordingly these reformist Muslims, sometimes called the "Salafis", would never tolerate religious practices and communities that opposed their strict Islamic conviction and beliefs. As a result of the purification movement, the "syncretic Muslims" such as Java's abangan (nominal Muslims) or Cambodia's Imam San had become one of the main targets of the reformists' Islamization and proselytization (da'wa) movement.

It is worth noting that in contemporary parlance the term Salafi has come to acquire many different connotations. It has been used to refer to some groups who consider it obligatory to take up arms against all those-Muslims and non-Muslims alike-who are deemed to challenge or contravene the dictates of the Islamic foundational texts-the Qur'an and the normative example of the Prophet Muhammad (the Sunna). The term also refers to a politically quietist trend, typified by the Saudi religious establishment, that rejects all 
beliefs and practices seen as compromising the ones of God (tawhid) while leaving politics largely to the ruling elite. The term Salafi, moreover, is also used for, and by, those who reject the authority of the medieval schools of law and insist on an unmediated access to the foundational texts as the source of all norms. The common use of the term Salafi or Salafism, however, is, in Zaman's phrase, "to denote an approach to Islam that was anchored in the foundational texts and in the example of the "pious forbears" as contrasted with understandings of Islam "distorted" by centuries of legal, theological, and mystical debates, self-serving ulama, and despotic rulers" (Zaman 2012: 6-7).

Equally important, apart from pros and cons of the rise of the Salafis or the reformists, they played a central role in the establishment of Islamic education institutions, particularly modern-type madrasas, for intermediate and advanced Islamic learning through which became one of the main channel of the process of Islamization throughout the regions of Southeast Asia. As some historians have noted these Islamic schools began to emerge in substantial numbers only toward the end of the $18^{\text {th }}$ and became widespread in Southeast Asia, particularly Java, Sumatra, Southern Thailand, and the Malay Peninsula, only in the final decades of the $19^{\text {th }}$ century. Only in the Southern Philippines, Cambodia, and Sulawesi did the madrasas appear in the first half of the $20^{\text {th }}$ century (see e.g. Hefner 2009: 16-7). These Islamic schools had been founded by kiais and ulama upon their return from their studies in the Middle East and Arab countries, especially the "Harramain" (Mecca and Medina).

The opening of Suez Canal in 1869 and steamship technology had made Southeast Asian Muslims more easily reaching Arabia. As a result, by 1885, Southeast Asian Muslims in the Arab lands composed the single largest community in Mecca and Medina, and by 1927, pilgrims from the British Malaya and the Dutch Indies comprised $42 \%$ of the foreign total pilgrims (see e.g. Laffan 2007, 2011). The effect of heightened travel to the Middle East, particularly Saudi Arabia and Egypt, toward the Southeast Asia's Islamic reformation, schooling, and social movement during the nineteenth century was obvious. Wahhabism and Salafism had been the one of the primary driving forces of the reformist movements. In Thailand, for instance, reformist Islam was also rooted in the $19^{\text {th }}$ Islamic reformism of the Salafi movement inspired by Egypt's Muhammad Abduh. This movement was brought by Ahmad Wahab, who established Ansor al-Sunah, Thailand's first reformist organization. Thus, it is clear that in Southeast Asia, the nineteenth century was a "tipping point" for a massive Islamic education and the process of Islamization as a whole.

The noted historian of Java Merle Ricklefs said that prior to the growing emergence of these Islamic reform movements in the $19^{\text {th }}$ century, in Java 
actually there had already been significant numbers of professionally religious peoples: mosque officials, religious teachers, guardians of holy sites, students of pesantrens, among others who were known collectively as kaum ("the religious folk") or putihan ("the white people") since the 1840s. On the northern coast of Java, these particular groups sometimes were called santri while the Dutch called them geestelijken: clericals, religious. There is no clear evidence whether such groups formed a force for Islamic puritanism, fundamentalism, or revivalism. However there are some similarities among those groups in the way they perceived the Javanese abangan as ignorant, backward, impure, and impious. Some puritan groups also sometimes called themselves kaum putihan. At the same time, the abangan (sometimes called abritan) responded negatively to the pressures for a more purified form of religious life advocated by the putihan. It is interesting that the tensions between the abangan and the putihan was not unique phenomena of Javanese religious society but also other parts of Southeast Asia such as the case of Imam San and Chvea in Cambodia or the community of "Islam Tua" and "Islam Muda" in the islands of Sulawesi's Sangihe-Talaud.

While the abangan since the late nineteenth century appeared as the majority social category and opposed the putihan's ideas of "the proper understanding of Islam," a tiny minority of Javanese rejected Islam and became Christians for the first time in the Javanese history, led by some extraordinary figures such as Kiai Ibrahim Tunggul Wulung, and above all, Kiai Sadrah Surapranata, who converted thousands of Javanese peoples to Christianity ${ }^{7}$ prior to his death in 1924 and then established the Javanese Christian Churches (Gereja Kristen Jawi), a mixture of European-Christian beliefs and Javanese cultures and concepts. Another faction of Javanese society was priyayi who enthusiastically embraced European learning and life style but still regarded themselves as Muslims, not Christians. Not all priyayi were happy with, and pragmatically embraced Islam, however, some priyayi rejected Islam altogether and wanted to return to the "Buda age" (i.e. an era of Hindu-Buddhism in pre-modern Java). For this particular group, the Islamization process of Javanese society was viewed as a great historical mistake; accordingly they advocated anti-Islamic movements and supported Budi-Buda teachings by tracing back to periods of the pre-Islamic Java. The emergence of anti-Islamic Javanese literatures such as Babad Kedhiri, Suluk Gatoloco, and Serat Dermogandhul in the 1870s can be seen from this point of view.

7 Today's Javanese/Indonesian Muslims very often have blamed the Dutch as the primary agent of religious conversion of local peoples to Christianity. Ricklefs (2007: 255) argued that the role of European missionaries in the conversion process was much less important than that of the Indo-European and indigenous Javanese proselytizers who successfully bridged the cultural gaps between Christianity and Javanese culture. 
The historical facts I depicted above suggest that the process of encounter of two or more different cultures on one hand could color and enrich each culture and tradition of societies, but on the other hand could cause conflicts and tensions. It is understandable because religion functions not only as a "social cohesion" as Emile Durkheim (1995) nicely asserted in his classic book The Elementary Forms of Religious Life, or a "social integration" as Clifford Geertz (1976) wrongly concluded in his The Religion of Java, but also serves as a vehicle of social conflicts. In the process of encounter, Javanese societies were not "passive recipient" so were Muslims and other "outsiders." They, instead, were active and influenced each other. To put it differently, each society has contributed in the process of interaction and encounter. This "creative tensions" have been well described in several Javanese texts and oral traditions: Aji Saka tale, Serat Centhini, and Javanese texts, commonly known babads, such as Serat Kandaning Ringgit Purwa, Babad Cerbon, Babad Tanah Jawi, and Serat Bental Jemur. Such creative tensions have produced the form of "salad" Islam of Javanese societies.

\section{JAVA'S ISLAMIC CONVERSION AND SOUTHEAST ASIA'S RELIGIOUS RESURGENCE}

As other parts of Southeast Asia, in Java, a critical turning point that marks the vitality of Islam-and, by definition, the collapse of Hindu-Buddhist influences-also happened in the $19^{\text {th }}$ century. One of the great examples or illustrations of such took place in the region of "Besuki" (not a real name) in East Java when in 1872 the wealthy Muslim entrepreneur and the grandson of a Tengger priest by the name of Haji Muhammad Saleh was elected by the villagers to be the village chief (Hefner 1987a: 61; 1989: 244). Although he was a Muslim, Hajj Muhammad Saleh was quite moderate and even utilized a famous tale of Aji Saka, a Javanese-pluralist cultural symbol that preserves the harmony between Islam and Javanese cultures and traditions to reconcile and bridge tensions between Muslims and Buda adherents.

The critical junctures that mark the abrupt decline of "Hindu-Buda" religion influence mostly took place in the era of post-Haji Muhammad Saleh in the late of nineteenth and the twentieth century. There were several critical moments that signified Islamization, conversion processes, and great sociocultural changes in this region. The first crucial moment was when the annual Karo festival had been replaced with annual village rite led by, not a Buda priest, an Islamic modin. The second moment was when the local Muslim community established a first mosque (c. 1922) in a former ancestral shrine that made the followers of Buda religion shocked. In the village of 
Wonorejo village, furthermore, the reformist Muslims cut down a tree where local people believed as the site of Nyai Po, the guardian spirit of the village. The third factor was about in the 1930s when Muhammadiyah reformists launched a program of reformed religious education in Besuki and several neighboring villages. The fourth was during the Indonesian independence struggle, especially when a village leader of a devoted modernist Muslim and progressive administrator launched road-building programs, a drinking water project, home reconstruction, and religious reforms by banning public consumption of alcohol, public dancing (e.g. tayub), and the recitation of Aji Saka story (Hefner 1987a: 66; 1989: 246).

Finally the big wave of conversion to Islam occurred in the aftermath of the bloody the New Order-led anti-communist events of 1965-1966 when the new regime of Indonesia obliged its peoples to embrace one of the Indonesia's official religions: Islam, Catholicism, Protestantism, Buddhism, and Balinese "reformed" Hinduism. At present, Confucianism becomes the state's official religion. Although there was no physical violence in the region due to no communist members and organizers had been found in it, the Besuki people were scared due to rumors spread throughout the region that persons not professing one of the state's recognized religions could be accused of being communist. This moment had been utilized by the village's Muslim chief to offer Buda followers of Besuki in order to identify themselves as Muslim with a compensation of protecting the Karo rite tradition.

While Buda followers of Besuki had been offered to acknowledge Islam, the Hindu followers of Tengger preferred to merge to Balinese Hinduism. The peak of Islamization and conversion process in Besuki and other part of Java and Indonesia was absolutely during the New Order in which through the Department of Religious Affairs, the regime had sponsored Islamic dakwah movements by building mosques, religious schools, madrasas and other religious institutions across the country as well as by sending Islamic preachers ( ${ }^{\prime}{ }^{\prime} i$, mubaligh) and religious schoolteachers to Indonesian towns and villages. These facts have proved that the New Order was not "anti-Islamic" as some observers might think. Indeed, the regime pushed back Muslim political parties by prohibiting Masyumi and other radical Muslim groups, but the New Order greatly sponsored those Islamic dakwah activities.

The phenomena above have pictured well the lengthy process of Java's Islamization and conversion from local religions-Hindu, Buddha, animism, "Javanism," etc. - to Islam. There were various patterns and dynamics of Java's Islamization, transformation, and conversion processes through period of time. At different times Islamization within modern Javanese history has 
been channeled to very different sociopolitical forces. In the $19^{\text {th }}$ and early $20^{\text {th }}$ centuries for instance Islamization process went hand in hand with the increase of pesantren institutions, religious schools, and economic structures. While during the Old Order Islamization was linked to aliran (lit. "streaming") pattern of party mobilization, in the time of the New Order it strongly related to educational programs and dakwah movements.

In addition, the cases illustrated above capture the dynamics of Java's Islamization and lengthy conversion processes from local and "small-scale" Javanese religions to the "transnational" and "world" religion, notably Islam. This "great conversion" to new world religions, as I noticed in the previous paragraphs, had been common view and widespread phenomena in Southeast Asia since the late nineteenth and early twentieth century, and this conversion continues nowadays. The term "religious conversion" used in this essay refers not only to a religious or theological change, but also to include a shift from a particular religious identity within a single religious tradition. Contemporary Southeast Asia and Asia, more generally (except Japan or North Korea), has been marked by, among others, this later sort of conversion and religious resurgence, namely an unprecedented upsurge in religious ritual, association, and observance.

In the once securely Catholic Philippines, the past generation has been dramatic conversion to evangelical and Pentecostal Christianity (Howell 2008). Vietnam, since the Doi Moi reforms of the late 1980s has also witnessed the resurgence of ritual practice (Malarney 2002). The ritualist surge includes not just the revival of long-suppressed household rites, but also the expansion of public cults such as the Lady of the Realm goddess in southern Vietnam (Taylor 2004). In the Theravada Buddhist lands of Burma, Thailand, and Cambodia, the past generation has also witnessed a steady expansion in lay devotion such as meditation movements that square off against a regime-backed Buddhism. The Theravada movements share a characteristic with Pentecostal and charismatic Christians across Southeast Asia, namely the prominence of women in their ranks. Over the past generation, Muslim Southeast Asia has also experienced a dramatic religious revitalization. Whereas two generations ago, Southeast Asia was renowned for the home-grown varieties of Islam, today, Saudiinspired Salafiyyah conservatives, Hizbut Tahrir internationalists, Indiabased Jamaah Tabligh, and the Middle East-typed Muslim Brothers move effortlessly across the region. Although Southeast Asia's Islamic resurgence shows clear global influences, the universalized influences find their meaning in "concrete engagement" not in "abstract principles of knowledge and power" (Tsing 2005: 67). 
To some degree, this immense religious change from "traditional" and "indigenous" religions to new religious beliefs as well as a shift from established world religions to new variants within the same but internationally-linked world religions resembles the collapse of small home industries by the emergence of transnational corporation (TNC) in the economic world. The analyses depicted above suggest that religion is not simply a matter of individual belief and personal faith but, at some point, also a social institution which-like other institutions-depends upon a particular social and political configuration for its reproduction as well as religious agents as the producer of religious discourses. Moreover, the historical facts and analyses I sketched above suggest that religious conversion-whether in the sense of a change of religion or a shift of particular religious identity within a single religious-is not simply a matter of individual choice and personal evaluation toward certain religion or religious groups but a social problem linked to the construction of political institutions under which some meanings would be shared and others denied. The political economy of religious culture, hence, ensures this massive conversion and transformation process and asserts the nature, existence, and function of religion as both belief system and institution in the social-cultural field of Southeast Asia.

\section{BIBLIOGRAPHY}

Beatty, Andrew. 1999. Varieties of Javanese Religion: An Anthropological Account. Cambridge: Cambridge University Press.

Djamil, Abdul. 2001. Perlawanan Kiai Desa: Pemikiran dan Gerakan K.H. Ahmad Rifai Kalisalak. Yogyakarta: LKiS.

Durkheim, Emile. 1995. The Elementary Forms of Religious Life. New York: Free Press.

Geertz, Clifford. 1976. The Religion of Java. Chicago, IL: The University of Chicago.

Hefner, Robert W. 2010. "Religious Resurgence in Contemporary Asia: Southeast Asian Perspectives on Capitalism, the State, and the New Piety. The Journal of Asian Studies 69 (4): 1003-1047. . (ed.). 2009. Making Modern Muslims: The Politics of Islamic Education in Southeast Asia. Honolulu: University of Hawai'i Press. . 1989. Hindu Javanese: Tengger Tradition and Islam. Princeton, NJ: Princeton University Press.

1987. "Islamizing Java? Religion and Politics in Rural East Java." The Journal of Asian Studies 46 (3): pp. 533-54.

Howell, Brian. 2008. Christianity in the Local Context: Southern Baptists in the 
Philippines. New York: Palgrave Macmillan.

Kartodirdjo, Sartono. 1973. Protest Movements in Rural Java. Oxford, UK: Oxford University Press.

Laffan, Michael. 2011. The Making of Indonesian Islam: Orientalism and the Narration of a Sufi Past. Princeton, NJ: Princeton University Press. . 2007. Islamic Nationhood and Colonial Indonesia: The Umma Below the Winds. New York: Routledge.

Lockard, Craig. 2009. Southeast Asia in World History. New York: Oxford University Press.

Lombard, Denys. Nusa Jawa Silang Budaya. Jakarta: Gramedia.

Malarney, Shaun Kingsley. 2002. Culture, Ritual, and Revolution in Vietnam. New York: Routledge Curzon.

McKenna, Thomas. 1998. Muslim Rulers and Rebels: Everyday Politics and Armed Separatism in the Southern Philippines. California: California University Press.

Nio, Joe Lan. 1952. Tiongkok Sepandjang Abad. Djakarta: Gunung Agung.

Osborne, Milton. 2000. Southeast Asia: An Introductory History. Australia: Allen \& Unwin . 2002. Exploring Southeast Asia: A Traveler's History of the Region. Australia: Allen \& Unwin.

Pigeaud, Theodore G. Th. 1962. Java in the $14^{\text {th }}$ Century. New York: Springer.

Reid, Anthony. 1988/1995. Southeast Asia in the Age of Commerce, 2 vol. New Haven, CT: Yale Univ. Press.

Ricklefs, M.C. 2007. Polarizing Javanese Society: Islamic and other Visions (c. 1830-1930). Singapore: NUS Press.

Schrieke, B. 1957. Ruler and Realm in Early Java. The Hague and Bandung: W. van Hoeve Ltd.

SarDesai, D.R. 1997. Southeast Asia: past and Present. Boulder, CO: Westview.

Tan, Ta Sen. 2009. Cheng Ho and Islam in Southeast Asia. Singapore: ISEAS.

Taylor, Philip. 2004. Goddess on the Rise: Pilgrimage and Popular Religion in Vietnam. Honolulu: University of Hawaii Press.

Tsing, Anna Lowenhaupt. 2005. Friction: An Ethnography of Global Connection. Princeton, N.J.: Princeton University Press.

Weber, Max. 1993. The Sociology of Religion. Boston, MA: Beacon Press.

Widodo, Johannes. 2003. "Admiral Zheng He and Pre-Colonial Coastal Urban Development in Southeast Asia”. Inaugural Lecture organized by Friends of Zheng He Society. Singapore (unpublised manuscript).

Wolters, Oliver. 1993. History, Culture, and Region in Southeast Asian Perspectives. Itacha, NY: Cornell University Press.

Zaman, Muhammad Qasim. 2012. Modern Islamic Thought in a Radical Age: 
Religious Authority and Internal Criticism. New York: Cambridge University Press. 
